\title{
EFFECTS OF REGULAR AND CONDITIONED SMALL-SIDED GAMES ON YOUNG FOOTBALL PLAYERS' HEART RATE RESPONSES, TECHNICAL PERFORMANCE, AND NETWORK STRUCTURE
}

original paper

doi: https://doi.org/10.5114/hm.2017.73618

\author{
SIXTO GONZÁLEZ-VÍLLORA ${ }^{1}$, FILIPE MANUEL CLEMENTE ${ }^{2,3}$, \\ FERNANDO M.L. MARTINS ${ }^{3,4}$, JUAN CARLOS PASTOR-VICEDO ${ }^{5}$ \\ ${ }^{1}$ Teacher Training Faculty of Cuenca, University of Castilla-La Mancha, Cuenca, Spain \\ ${ }^{2}$ Instituto Politécnico de Viana do Castelo, Escola Superior de Desporto e Lazer, Viana do Castelo, Portugal \\ ${ }^{3}$ Instituto de Telecomunicações, Delegação da Covilhã, Portugal \\ ${ }^{4}$ Instituto Politécnico de Coimbra, Escola Superior de Educação, Departamento de Educação, IIA, RoboCorp, ASSERT, \\ Coimbra, Portugal \\ ${ }^{5}$ Teacher Training Faculty of Albacete, University of Castilla-La Mancha, Albacete, Spain
}

\section{ABSTRACT}

Purpose. The purpose of this original work was to analyse the effects of different formats and task conditions in regular small-sided games (SSG) and small-sided conditioned games (SSCG) on heart rate profile and tactical-technical performance (measured by Network and Team Sport Assessment Procedure) among young football players.

Methods. The total of 16 male elite young players (age: $11.6 \pm 0.8$ years; practice: $3 \pm 1.4$ years) were tested. Each participant played in six different formats, namely three 3-a-side games and three 5-a-side games: (i) regular SSG, (ii) attacking contentspace SSCG, (iii) defensive content-concentration SSCG. Each game lasted 5 minutes, and 3 minutes of passive recovery between games was adopted.

Results. Different formats did not result in statistical differences in heart rate responses. Nevertheless, significant differences were found between formats in technical performance $(\mathrm{p}<0.05)$ and collective organization measured by network $(p<0.05)$. No statistical differences were observed between task conditions with tactical content in technical performance and collective organization.

Conclusions. The conditions used in this study may enable coaches/teachers to carry out a more quality and specific training, helping to understand the real effects of SSG/SSCG: smaller formats increase the tactical-technical participation, time in high intensity heart rate, and network density.

Key words: network analysis, graph theory, task conditions, heart rate, youth sport (U12), game performance analysis

\section{INTRODUCTION}

The game of football is a complex team sport that depends on coordination processes within and between players during matches [1] or small-sided games (SSG) and small-sided conditioned games (SSCG). SSGs are specific tasks designed in the scope of football training to improve the possibility of players' development [2]. They are part of a training strategy that coaches or physical education teachers use to improve the practice of football or other team sports [3]. These games aim to ensure the ecology of training sessions by replying the dynamic of a full-match [2].

In each SSG, it is possible to train different indicators of performance, such as physical activity, physiological responses, technical actions, and tactical behaviours [4]. It is also possible to simultaneously develop players' physical, technical, and tactical performance [5].

The use of smaller formats of the game may raise the individual participation of players in a sport, and provides interesting physiological responses [4]. For that reason, SSGs are relevant learning activities to

Correspondence address: Sixto González-Víllora, Facultad de Educación de Cuenca, Universidad de Castilla-La Mancha, Camino Pozuelo, s/n, 16071 Cuenca, Spain, e-mail: Sixto.Gonzalez@uclm.es

Received: October 16, 2017

Acepted for publication: January 4, 2018

Citation:González-VílloraS,ClementeFM,MartinsFML,Pastor-VicedoJC.Effectsofregularandconditionedsmall-sidedgames on young football players' heart rate responses, technical performance, and network structure. 2017;18(5)special/issue: 135-145; doi: https://doi.org/10.5114/hm.2017.73618. 
S. González-Víllora, F.M. Clemente, F.M.L. Martins, J.C. Pastor-Vicedo, Performance in conditioned soccer games

use in the training plan from young to professional players [6, 7]. In fact, SSGs, quite valuable for football training, constitute an interesting topic to be researched in sports sciences.

Previous studies on football SSGs are associated with changes in the format of the game or size of the field. Sports researchers are becoming interested by study performance variables that can be affected by SSGs [8]. The format of the game is one of the task conditions most analysed, the main point of interest being that smaller formats ( 1 vs. 1,2 vs. 2 , and 3 vs. 3 ) statistically increase positive physiological responses relative to bigger game formats ( 4 vs. 4,5 vs. 5 , and 6 vs. 6) [9]. The size of the field has been the focus of studies investigating the influence of smaller, medium, or large dimensions in each SSG [10]. The majority of studies have reported that bigger dimensions increase the physiological responses of players (heart rate responses and blood lactate concentration) [11]. Moreover, other task conditions, such as individual contacts on ball location, the non-use of goalkeepers [12], different goals [4], and the use of neutral players, may also affect the physiological and tactical-technical responses [13].

Another perspective of SSG research is the analysis of the tactical principles that players apply in the games. Tactical contexts in invasion games can be grouped together according to action principles [14]. In attack, action principles include maintaining possession of the ball, penetrating the defence (moving toward the goal), and attacking the goal. The tactical awareness and decision making aspects of SSGs have been studied with different numbers of players ( 2 vs. 2,3 vs. 3,5 vs. 5 , and 7 vs. 7 ) and ages (Under- 8 [U8], U10, U12, and U14) [15].

A further step in this type of research has been gamecentred approaches' pedagogical principles, exploring task constraints in youth football [7]. Three studies compared the performance of U10 football players in two modified games 3 vs. 3 . In the three studies, the first SSG was modified by representation. The second game was modified by enhancing or exaggerating one tactical principle: first study - maintaining possession of the ball [16]; second study - the penetration of the defence [7]; third study - attacking the goal [17]. In these studies, the task constraint was the modification of the highest tactical principle in the game, so the game of exaggeration would be SSCG.

Nevertheless, these changes are too limited for the opportunities perceived by coaches [1] and physical education teachers. In fact, in the specific case of youth players, the changes in SSG vary the rules and even the structure of the game, trying to increase the perception of players to specific technical actions, tactical behaviours, and decision-making processes [6]. Therefore, it is important to increase the analysis in the aim of conditioned games, thus representing a change in the regular terminology of SSGs to a new concept of SSCGs [1, 4].

Therefore, the aim of this study was to analyse the variance between all formats and conditioned games: two SSGs: 3-a-side and 5-a-side; two offensive SSCGs (space: width and length): 3-a-side and 5-a-side; two defensive SSCGs (concentration): 3-a-side and 5-a-side. The heart rate responses, time-motion characteristics, and tactical-technical analysis (Network and Team Sport Assessment Procedure [TSAP]) were examined throughout the six games in 16 U12 elite young players. We hypothesized that smaller formats increased the heart rate responses and number of technical actions; small-to-non differences would occur between the conditioned games.

\section{MATERIAL AND METHODS}

\section{Sample}

A sample of 16 U12 Albacete Balompié elite male football players aged $11.6 \pm 0.8$ years was selected. The football club has a football academy with a reserve of young players making up 21 youth teams, from 6 to 19 years of age. Players are selected by means of their play level both in Spain and abroad; therefore, they are highly-skilled or talent-identified players. The professional team competes in the Spanish second division although some years ago it competed in the Spanish first division or Liga (for 7 seasons). For this study, the best 16 U12 players were selected out of the 56 U12 ones in the three teams. Before the research, the 16 players were familiarized with the experimental procedures. The study followed the Declaration of Helsinki and was approved by the Ethics Committee from the Polytechnic Institute of Coimbra, approval \# ESEC.O01.03.15, and the Ethics Review Committee from Albacete, University of Castilla-La Mancha.

\section{Data collection}

These 16 U12 players participated in three 3-a-side football games and three 5-a-side football games (Figures 1 and 2). The first SSG was modified by representation or neutral content (3-a-side and 5-a-side regular games). The second SSCG was attacking content-space or the attacking team should use one of the 


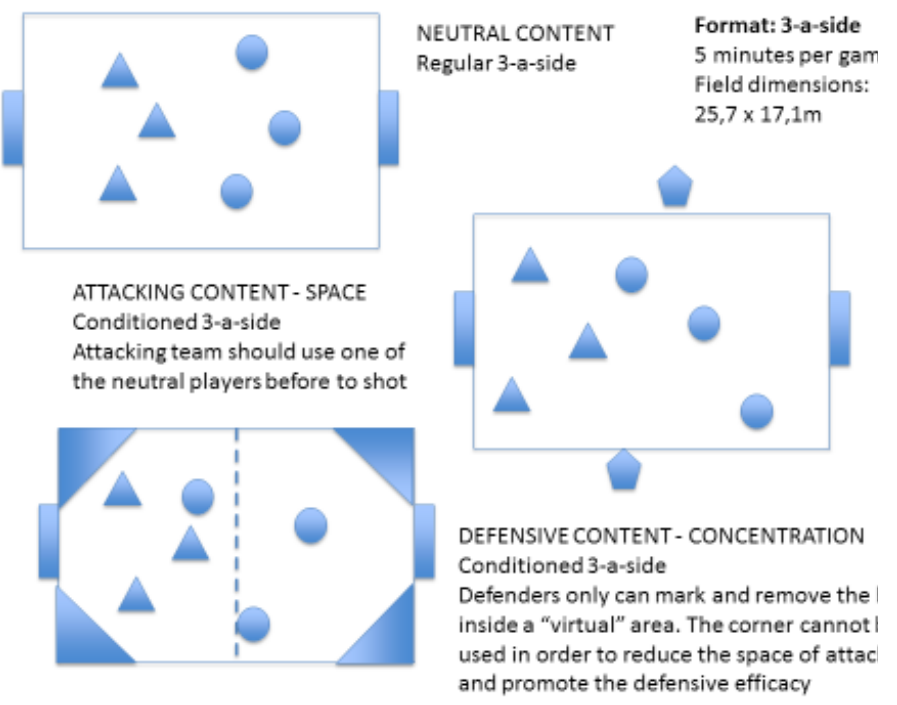

Figure 1. A 3-a-side football referential field

neutral players' places on the left and right sides before shooting (3-a-side and 5-a-side game). The third SSCG was defensive content-concentration or the defenders only can mark and remove the ball inside a 'virtual' area. The corner cannot be used in order to reduce the space for attacking and promote defensive efficacy (3-a-side and 5-a-side games).

The tactical principles [18] that have been used in SSCGs were: attacking content-space (width and length) and defensive content-concentration. Therefore, space was defined as the movement of players to extend and use the play-space effectively (width and length), and concentration was defined as the positioning of off-ball defenders to occupy vital spaces and protect the scoring area.

The six games lasted for 5 minutes, with 3 minutes of passive recovery between them. Prior to the games, the players participated in a similar warm-up consisting of general mobility and stretching exercises. Then, the game rules were explained to them (oral communication and support of tactical slate), and they practiced the game for 2 minutes before the recording.

The teams' actions were captured with a digital camera (Sony with $1280 \times 960$ resolution), with the capacity to process images at $30 \mathrm{~Hz}$ (i.e. 30 frames per second). The camera was placed on an elevated surface above the ground in a way allowing to capture the whole field ( $4 \mathrm{~m}$ high). The field dimensions were $25.7 \times 17.1 \mathrm{~m}$ for 3 -a-side games and $42.8 \times 28.6 \mathrm{~m}$ for 5 -a-side games. The goals were reduced in size $(3 \times$ $1.8 \mathrm{~m}$ for 3 -a-side games and $4 \times 2 \mathrm{~m}$ for 5 -a-side games) and the balls were size 4 .

The players' game performance was codified in the SSG and SSCG with the use of heart rate and time-

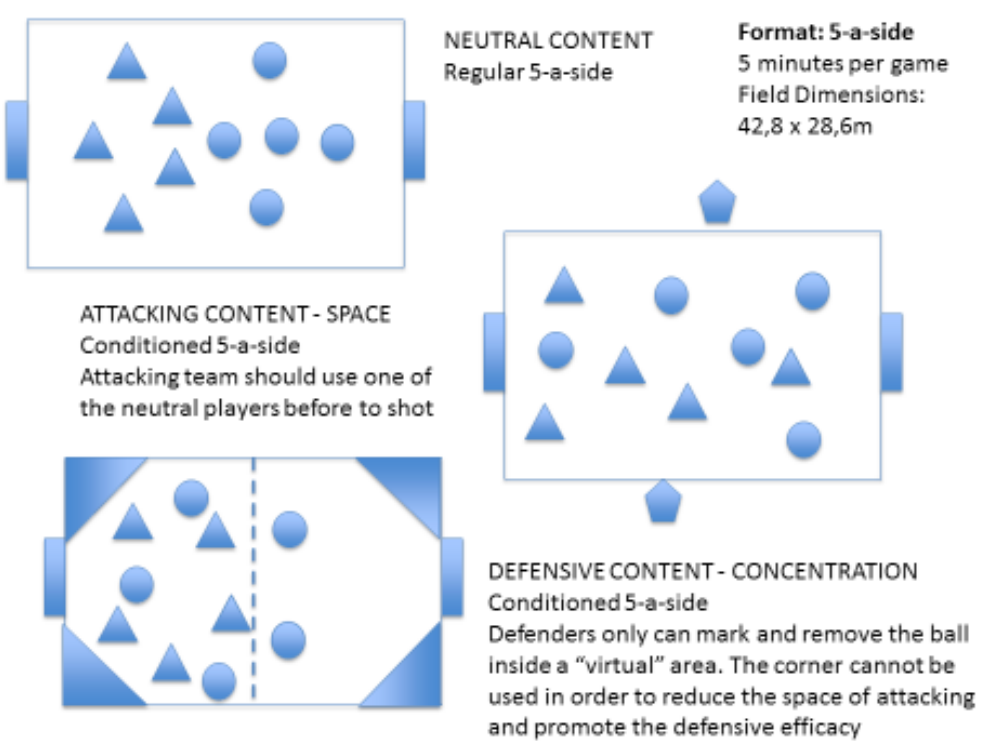

Figure 2. A 5-a-side football referential field

motion characteristics as physical and physiological analysis; Network [19, 20] and TSAP [21] as tacticaltechnical analysis.

Physiological analysis

To assess the heart rate responses during SSG and SSCG, the heart rate monitors placed on the players' chests were continuously used. The heart rate was recorded at 1-second intervals by a lightweight and portable heart rate monitor (Polar Team App, Finland).

All heart rate data were downloaded and stored in a computer using dedicated software (Polar WebSync and Polar Pro Trainer 5.0). The \%HR reserve (percentage of heart rate reserve) was computed with Karvonen's method to measure the players' responses.

Assessment of tactical-technical performance

The TSAP was designed by Gréhaigne et al. [21]. The tool takes into account the interactions between both tactical and technical efficiency. The evaluation procedure is strictly game-oriented and yields information reflecting both motor and tactical skills. The objective is to assess individual performance in team sports in contexts of pre-assessment and formative assessment. An authentic assessment procedure based on the observation of players' actions during matches yielded two performance indices: the efficiency index and the volume of play [21]. The tactical-technical performance was analysed on the basis of the TSAP protocol [22]. TSAP evaluates the observational indicators that appear in Table 1. 


\section{HUMAN MOVEMENT}

S. González-Víllora, F.M. Clemente, F.M.L. Martins, J.C. Pastor-Vicedo, Performance in conditioned soccer games

Table 1. Relationships between observation items and types of information collected [23]

\begin{tabular}{|c|c|c|}
\hline Observation items & Description & Information collected \\
\hline Received balls (RB) & Passes received from colleagues & Involvement of the player in the team's play \\
\hline Conquered balls (CB) & Balls recovered from the opponents & Defensive capacities of the player \\
\hline Offensive balls (OB) & Passes moving forward & $\begin{array}{l}\text { The player's capacity to make significant passes to their } \\
\text { partners (offensive capacities) }\end{array}$ \\
\hline Successful shots (SS) & Shots that originated goals & The player's offensive capacities \\
\hline Volume of play (VP) & Sum of $\mathrm{CB}$ and $\mathrm{RB}$ & General involvement of the player in the game \\
\hline Lost balls (LB) & Number of lost balls made by a player & A small number reflects a good adaptation to the game \\
\hline
\end{tabular}

With the use of the indicators, it was possible to compute the following equations:

(i) volume of play:

$$
\begin{aligned}
& \text { Volume of Play }(V P)=C B+R B \\
& \text { Volume of Play }(V P)=C B+R B
\end{aligned}
$$

(ii) attacks with ball:

$$
\text { Attacks with ball }(A B)=P+S S
$$$$
\text { Attacks with ball }(A B)=P+S S
$$

(iii) efficiency index:

$$
\begin{aligned}
& \text { Efficiency Index }(E I)=\frac{A B}{10+L B} \\
& \text { Efficiency Index }(E I)=\frac{A B}{10+L B}
\end{aligned}
$$

(iv) performance score:

$$
\begin{aligned}
& \text { Performance Score }(P S)=\left(\frac{V P}{2}\right)+(E I \times 10) \\
& \text { Performance Score }(P S)=\left(\frac{V P}{2}\right)+(E I \times 10)
\end{aligned}
$$

The observational process was performed after video collection by the same researcher with experience in match analysis. The reliability was tested with a testretest protocol followed by Cohen's kappa test [24]. After testing $15 \%$ of the full data, the kappa value of 0.95 was observed, which meant achieving the recommended value for this type of procedure.

\section{Network measurements}

The study analysed the teammates' interaction during attacking moments on the basis of a social network analysis. This approach has been used in the last few years in order to identify the tendencies of interactions between teammates [20]. In our case, only the attacking interaction, represented by passes between teammates, was analysed. The protocol of observation followed previous studies in this field of analysis [19]. The network metrics presented below were computed in SocNetV (version 1.9).

\section{Graph density}

In graph theory, the density of a (directed) graph is the proportion of the maximum possible lines (or arcs) that are present between nodes [19].

\section{Clustering coefficient}

Thus the local clustering coefficient measures the degree of interconnectivity in the neighbourhood of a node. The higher it is, the closer the node and its neighbours are to becoming a clique [19].

\section{Total arcs}

Each element $a_{i j}$ of the adjacency matrix was the number of interactions (passes) from player $i$ to player $j$ and, in terms of the corresponding weighted digraph (sociogram) produced by SocNetV, it was represented by a directed line (arc) between node $n_{i}$ and node $n_{j}$. Links (passes) were between each team's players. In the corresponding weighted directed graph, this number is the total arcs between all nodes.

\section{Statistical procedures}

The influences of format (3-a-side and 5-a-side) and conditions (T1 - regular; T2 - defensive; T3 - attacking) on the \%HRmax, \%Time per HRmax Zone (\% of total time), volume of play, efficiency index, performance score, graph density, and clustering coefficient were analysed with the use of two-way MANOVA after validating normality and homogeneity assumptions.

When the two-way ANOVA showed an interaction between factors, it also generated a new variable that crossed the two factors (e.g., 3vs. $3{ }^{*} \mathrm{~T} 1 ; 3 \mathrm{vs} .3^{*} \mathrm{~T} 2$ ) for each dependent variable to identify statistical sig- 
nificance. Ultimately, the statistical procedures used were one-way ANOVA and Tukey HSD post-hoc. If no interactions were detected in two-way ANOVA, a one-way ANOVA was used for each independent variable. All statistical analyses were performed with the IBM SPSS Statistics (version 22), with the significance level of $p<0.05$. The following scale was used to classify the effect size (partial eta square) of the test: small: 0.2-0.49; moderate: 0.50-0.79; large: 0.80-1.

\section{Ethical approval}

The research related to human use has been complied with all the relevant national regulations, institutional policies and in accordance the tenets of the Helsinki Declaration, and has been approved by the authors' institutional review board or equivalent committee.

\section{RESULTS}

\section{Heart rate analysis}

The two-way MANOVA revealed that the task condition ( $p=0.025 ; \eta_{p}^{2}=0.132$; small effect size) had significant main effects on the heart rate responses. No differences were found in format $\left(p=0.600 ; \eta_{p}^{2}=\right.$ 0.055 ; small effect size). There was a significant interaction (Pillai's trace $=0.292 ; F=2.276 ; p=0.011$; $\eta_{p}^{2}=0.146$; small effect size) between format and task condition on heart rate variables. As previously indicated in the statistical procedures, a two-way ANOVA was conducted for each dependent variable after the confirmation of the interaction.

Interaction was found between factors for \%HRmax average $\left(F=3.162 ; p=0.047 ; \eta_{p}^{2}=0.070\right.$; small effect size $)$ and Z5 $\left(F=3.673 ; p=0.030 ; \eta_{p}^{2}=0.080\right.$; small effect size). No interactions were found for Z1 $\left(F=2.841 ; p=0.047 ; \eta_{p}^{2}=0.070 ;\right.$ small effect size $)$, $\mathrm{Z2}\left(F=0.124 ; p=0.884 ; \eta_{p}^{2}=0.003\right.$; small effect size), Z3 $\left(F=1.659 ; p=0.197 ; \eta_{p}^{2}=0.038\right.$; small effect size) or Z4 ( $F=3.054 ; p=0.052 ; \eta_{p}^{2}=0.068$; small effect size).

The one-way ANOVA tested the crossing between factors. Statistical differences were not found between the new variable (cross between format and task condition) and the dependent variables of \%HR average $\left(F=1.311 ; p=0.267 ; \eta_{p}^{2}=0.072\right.$; small effect size $)$ and Z5 $\left(F=1.529 ; p=0.190 ; \eta_{p}^{2}=0.083\right.$; small effect size). The results observed are shown in Table 2 .

In the case of Z1, Z2, Z3, and Z4, a one-way ANOVA was performed for each independent variable because no interaction was found between factors. The statistical values that resulted from the comparison between task conditions can be observed in Table 3 .

The one-way ANOVA was also carried out to compare the values between formats for the variables of Z1, Z2, Z3, and Z4. The values are presented in Table 4 .

\section{Technical performance}

The two-way MANOVA revealed that the format $\left(p=0.001 ; \eta_{p}^{2}=0.340\right.$; small effect size $)$ and task condition ( $p=0.001 ; \eta_{p}^{2}=0.120$; small effect size) had significant main effects on the technical performance. There was no significant interaction (Pillai's trace $=$ $0.039 ; F=0.846 ; p=0.498 ; \eta_{p}^{2}=0.020$; small effect size) between format and task condition on technical performance.

In the case of volume of play, efficiency index, and performance score, a one-way ANOVA was performed for each independent variable because no interaction was found between factors. The statistical values that resulted from the comparison between task conditions can be observed in Table 5 .

One-way ANOVA was also carried out to compare the values between formats for the variables of volume of play, efficiency index, and performance score. The values can be verified in Table 6 .

\section{Network analysis}

The two-way MANOVA revealed that the format $\left(p=0.001 ; \eta_{p}^{2}=0.998\right.$; large effect size) had significant main effects on the teammates' network. No statistical differences were found in task condition $(p=0.867$; $\eta_{p}^{2}=0.191 ;$ small effect size). There was no significant interaction (Pillai's trace $=0.383 ; F=0.394 ; p=0.867$;

Table 2. Descriptive table (mean and standard deviation) and statistical comparison between crossing factors

\begin{tabular}{lcccccc} 
& \multicolumn{3}{c}{3 vs. 3} & & & 5 vs. 5 \\
& Task 1 & Task 2 & Task 3 & Task 1 & Task 2 & Task 3 \\
\hline \%HRmax average & $85.33(4.79)$ & $88.60(5.69)$ & $86.13(4.81)$ & $88.80(7.08)$ & $85.07(4.64)$ & $87.80(6.16)$ \\
\hline Z5 & $32.20(24.50)$ & $49.33(27.85)$ & $41.47(22.09)$ & $53.00(29.77)$ & $33.07(24.61)$ & $44.73(29.28)$
\end{tabular}




\section{HUMAN MOVEMENT}

S. González-Víllora, F.M. Clemente, F.M.L. Martins, J.C. Pastor-Vicedo, Performance in conditioned soccer games

Table 3. One-way ANOVA values of task conditions per format in Z1, Z2, Z3, and Z4

\begin{tabular}{|c|c|c|c|c|c|c|}
\hline & & & $M(S D)$ & $F$ & $p$ & $\eta_{p}^{2}$ \\
\hline \multirow{2}{*}{$\mathrm{Z1}$} & 3 vs. 3 & $\begin{array}{l}\text { T1 } \\
\text { T2 } \\
\text { T3 }\end{array}$ & $\begin{array}{l}3.13(2.70)^{\mathrm{b}, \mathrm{c}} \\
1.07(1.79)^{\mathrm{a}} \\
0.60(1.18)^{\mathrm{a}}\end{array}$ & 6.888 & 0.003 & 0.247 \\
\hline & 5 vs. 5 & $\begin{array}{l}\text { T1 } \\
\text { T2 } \\
\text { T3 }\end{array}$ & $\begin{array}{l}0.87(1.73) \\
1.40(3.70) \\
0.33(0.90)\end{array}$ & 0.732 & 0.487 & 0.034 \\
\hline \multirow[b]{2}{*}{$\mathrm{Z} 2$} & 3 vs. 3 & $\begin{array}{l}\text { T1 } \\
\text { T2 } \\
\text { T3 }\end{array}$ & $\begin{array}{l}5.87(5.83) \\
6.20(7.42) \\
3.20(2.40)\end{array}$ & 1.284 & 0.288 & 0.058 \\
\hline & 5 vs. 5 & $\begin{array}{l}\text { T1 } \\
\text { T2 } \\
\text { T3 }\end{array}$ & $\begin{array}{l}5.00(12.06) \\
5.53(5.46) \\
4.00(5.53)\end{array}$ & 0.132 & 0.876 & 0.006 \\
\hline \multirow{2}{*}{ Z3 } & 3 vs. 3 & $\begin{array}{l}\text { T1 } \\
\text { T2 } \\
\text { T3 }\end{array}$ & $\begin{array}{c}13.13(9.36) \\
10.80(10.85) \\
13.00(10.40)\end{array}$ & 0.246 & 0.783 & 0.012 \\
\hline & 5 vs. 5 & $\begin{array}{l}\text { T1 } \\
\text { T2 } \\
\text { T3 }\end{array}$ & $\begin{array}{r}7.27(9.75) \\
15.07(11.39) \\
12.13(12.57)\end{array}$ & 1.824 & 0.174 & 0.080 \\
\hline \multirow{2}{*}{$\mathrm{Z4}$} & 3 vs. 3 & $\begin{array}{l}\text { T1 } \\
\text { T2 } \\
\text { T3 }\end{array}$ & $\begin{array}{l}45.80(18.45) \\
32.60(16.74) \\
41.73(16.30)\end{array}$ & 2.321 & 0.111 & 0.100 \\
\hline & 5 vs. 5 & $\begin{array}{l}\text { T1 } \\
\text { T2 } \\
\text { T3 }\end{array}$ & $\begin{array}{l}33.87(23.19) \\
44.93(18.64) \\
38.80(21.13)\end{array}$ & 1.039 & 0.363 & 0.047 \\
\hline
\end{tabular}

Significantly different compared with $\mathrm{T}^{\mathrm{a}}$; $\mathrm{T}^{\mathrm{b}}$; and $\mathrm{T}^{\mathrm{c}}$ at $p<0.05$

Table 4. One-way ANOVA values of format per task conditions in Z1, Z2, Z3, and Z4

\begin{tabular}{|c|c|c|c|c|c|c|}
\hline & & & $M(S D)$ & $F$ & $p$ & $\eta_{p}^{2}$ \\
\hline \multirow{3}{*}{$\mathrm{Z1}$} & Task 1 & $\begin{array}{l}3 \text { vs. } 3 \\
5 \text { vs. } 5\end{array}$ & $\begin{array}{l}3.13(2.70)^{\mathrm{b}} \\
0.87(1.73)^{\mathrm{a}}\end{array}$ & 7.520 & 0.011 & 0.212 \\
\hline & Task 2 & $\begin{array}{l}3 \text { vs. } 3 \\
5 \text { vs. } 5\end{array}$ & $\begin{array}{l}1.07(1.79) \\
1.40(3.70)\end{array}$ & 0.099 & 0.756 & 0.004 \\
\hline & Task 3 & $\begin{array}{l}3 \text { vs. } 3 \\
5 \text { vs. } 5\end{array}$ & $\begin{array}{l}0.60(1.18) \\
0.33(0.90)\end{array}$ & 0.483 & 0.493 & 0.017 \\
\hline \multirow{3}{*}{$\mathrm{Z} 2$} & Task 1 & $\begin{array}{l}3 \text { vs. } 3 \\
5 \text { vs. } 5\end{array}$ & $\begin{array}{c}5.87(5.83) \\
5.00(12.06)\end{array}$ & 0.063 & 0.804 & 0.002 \\
\hline & Task 2 & $\begin{array}{l}3 \text { vs. } 3 \\
5 \text { vs. } 5\end{array}$ & $\begin{array}{l}6.20(7.42) \\
5.53(5.46)\end{array}$ & 0.079 & 0.781 & 0.003 \\
\hline & Task 3 & $\begin{array}{l}3 \text { vs. } 3 \\
5 \text { vs. } 5\end{array}$ & $\begin{array}{l}3.20(2.40) \\
4.00(5.53)\end{array}$ & 0.264 & 0.611 & 0.009 \\
\hline \multirow{3}{*}{$\mathrm{Z3}$} & Task 1 & $\begin{array}{l}3 \text { vs. } 3 \\
5 \text { vs. } 5\end{array}$ & $\begin{array}{c}13.13(9.36) \\
7.27(9.75)\end{array}$ & 2.825 & 0.104 & 0.092 \\
\hline & Task 2 & $\begin{array}{l}3 \text { vs. } 3 \\
5 \text { vs. } 5\end{array}$ & $\begin{array}{l}10.80(10.85) \\
15.07(11.39)\end{array}$ & 1.103 & 0.303 & 0.038 \\
\hline & Task 3 & $\begin{array}{l}3 \text { vs. } 3 \\
5 \text { vs. } 5\end{array}$ & $\begin{array}{l}13.00(10.40) \\
12.13(12.57)\end{array}$ & 0.042 & 0.839 & 0.002 \\
\hline \multirow{3}{*}{$\mathrm{Z} 4$} & Task 1 & $\begin{array}{l}3 \text { vs. } 3 \\
5 \text { vs. } 5\end{array}$ & $\begin{array}{l}45.80 \text { (18.45) } \\
33.87(23.19)\end{array}$ & 2.433 & 0.130 & 0.080 \\
\hline & Task 2 & $\begin{array}{l}3 \text { vs. } 3 \\
5 \text { vs. } 5\end{array}$ & $\begin{array}{l}32.60(16.74) \\
44.93(18.64)\end{array}$ & 3.635 & 0.067 & 0.115 \\
\hline & Task 3 & $\begin{array}{l}3 \text { vs. } 3 \\
5 \text { vs. } 5\end{array}$ & $\begin{array}{l}41.73(16.30 \\
38.80(21.13)\end{array}$ & 0.181 & 0.674 & 0.006 \\
\hline
\end{tabular}

Significantly different compared with 3 vs. $3^{\mathrm{a}}$ and 5 vs. $5^{\mathrm{b}}$ at $p<0.05$ 
Table 5. One-way ANOVA values of task conditions in each format for the volume of play, efficiency index, and performance score

\begin{tabular}{|c|c|c|c|c|c|c|}
\hline & & & $M(S D)$ & $\mathrm{F}$ & $\mathrm{p}$ & $\eta_{p}^{2}$ \\
\hline \multirow{2}{*}{ Volume of play } & 3 vs. 3 & $\begin{array}{l}\mathrm{T} 1 \\
\mathrm{~T} 2 \\
\mathrm{~T} 3\end{array}$ & $\begin{array}{c}11.00(3.40) \\
10.07(3.73) \\
9.93(3.41)\end{array}$ & 0.409 & 0.667 & 0.019 \\
\hline & 5 vs. 5 & $\begin{array}{l}\text { T1 } \\
\text { T2 } \\
\text { T3 }\end{array}$ & $\begin{array}{l}8.07(2.81) \\
4.67(2.32) \\
5.47(2.53)\end{array}$ & 7.213 & 0.002 & 0.256 \\
\hline \multirow{2}{*}{ Efficiency index } & 3 vs. 3 & $\begin{array}{l}\mathrm{T} 1 \\
\mathrm{~T} 2 \\
\mathrm{~T} 3\end{array}$ & $\begin{array}{l}0.35(0.15) \\
0.36(0.17) \\
0.44(0.25)\end{array}$ & 1.102 & 0.342 & 0.050 \\
\hline & 5 vs. 5 & $\begin{array}{l}\mathrm{T} 1 \\
\mathrm{~T} 2 \\
\mathrm{~T} 3\end{array}$ & $\begin{array}{l}0.27(0.14) \\
0.15(0.11) \\
0.33(0.21)\end{array}$ & 5.290 & 0.009 & 0.201 \\
\hline \multirow{2}{*}{ Performance score } & 3 vs. 3 & $\begin{array}{l}\mathrm{T} 1 \\
\mathrm{~T} 2 \\
\mathrm{~T} 3\end{array}$ & $\begin{array}{l}8.96(2.63) \\
8.60(3.12) \\
9.39(3.87)\end{array}$ & 0.223 & 0.801 & 0.011 \\
\hline & 5 vs. 5 & $\begin{array}{l}\mathrm{T} 1 \\
\mathrm{~T} 2 \\
\mathrm{~T} 3\end{array}$ & $\begin{array}{l}6.76(2.32) \\
3.79(2.11) \\
6.03(3.08)\end{array}$ & 5.609 & 0.007 & 0.211 \\
\hline
\end{tabular}

Table 6. One-way ANOVA values of formats per task conditions for the volume of play, efficiency index, and performance score

\begin{tabular}{|c|c|c|c|c|c|c|}
\hline & & & $M(S D)$ & $F$ & $p$ & $\eta_{p}^{2}$ \\
\hline \multirow{3}{*}{ Volume of play } & Task 1 & $\begin{array}{l}3 \text { vs. } 3 \\
5 \text { vs. } 5\end{array}$ & $\begin{array}{c}11.00(3.40)^{\mathrm{b}} \\
8.07(2.81)^{\mathrm{a}}\end{array}$ & 6.620 & 0.016 & 0.191 \\
\hline & Task 2 & $\begin{array}{l}3 \text { vs. } 3 \\
5 \text { vs. } 5\end{array}$ & $\begin{array}{c}10.07(3.73)^{\mathrm{b}} \\
4.67(2.32)^{\mathrm{a}}\end{array}$ & 22.658 & 0.001 & 0.447 \\
\hline & Task 3 & $\begin{array}{l}3 \text { vs. } 3 \\
5 \text { vs. } 5\end{array}$ & $\begin{array}{l}9.93(3.41)^{\mathrm{b}} \\
5.47(2.53)^{\mathrm{a}}\end{array}$ & 16.582 & 0.001 & 0.372 \\
\hline \multirow{3}{*}{ Efficiency index } & Task 1 & $\begin{array}{l}3 \text { vs. } 3 \\
5 \text { vs. } 5\end{array}$ & $\begin{array}{l}0.35(0.15) \\
0.27(0.14)\end{array}$ & 1.977 & 0.171 & 0.066 \\
\hline & Task 2 & $\begin{array}{l}3 \text { vs. } 3 \\
5 \text { vs. } 5\end{array}$ & $\begin{array}{l}0.36(0.17)^{\mathrm{b}} \\
0.15(0.11)^{\mathrm{a}}\end{array}$ & 15.987 & 0.001 & 0.363 \\
\hline & Task 3 & $\begin{array}{l}3 \text { vs. } 3 \\
5 \text { vs. } 5\end{array}$ & $\begin{array}{l}0.44(0.25) \\
0.33(0.21)\end{array}$ & 1.788 & 0.192 & 0.060 \\
\hline \multirow{3}{*}{ Performance score } & Task 1 & $\begin{array}{l}3 \text { vs. } 3 \\
5 \text { vs. } 5\end{array}$ & $\begin{array}{l}8.96(2.63)^{\mathrm{b}} \\
6.76(2.32)^{\mathrm{a}}\end{array}$ & 5.920 & 0.022 & 0.175 \\
\hline & Task 2 & $\begin{array}{l}3 \text { vs. } 3 \\
5 \text { vs. } 5\end{array}$ & $\begin{array}{l}8.60(3.12)^{\mathrm{b}} \\
3.79(2.11)^{\mathrm{a}}\end{array}$ & 24.525 & 0.001 & 0.467 \\
\hline & Task 3 & $\begin{array}{l}3 \text { vs. } 3 \\
5 \text { vs. } 5\end{array}$ & $\begin{array}{l}9.39(3.87)^{\mathrm{b}} \\
6.03(3.08)^{\mathrm{a}}\end{array}$ & 6.924 & 0.014 & 0.198 \\
\hline
\end{tabular}

Significantly different compared with 3 vs. $3^{\text {a }}$ and 5 vs. $5^{\text {b }}$ at $p<0.05$ 


\section{HUMAN MOVEMENT}

S. González-Víllora, F.M. Clemente, F.M.L. Martins, J.C. Pastor-Vicedo, Performance in conditioned soccer games

Table 7. One-way ANOVA values of task conditions in each format for network density, clustering coefficient, and total arcs

\begin{tabular}{|c|c|c|c|c|c|c|}
\hline & & & $M(S D)$ & $F$ & $p$ & $\eta_{p}^{2}$ \\
\hline \multirow{2}{*}{ Network density } & 3 vs. 3 & $\begin{array}{l}\text { T1 } \\
\text { T2 } \\
\text { T3 }\end{array}$ & $\begin{array}{l}1.00(0.00) \\
1.00(0.00) \\
0.92(0.12)\end{array}$ & 1.000 & 0.465 & 0.400 \\
\hline & 5 vs. 5 & $\begin{array}{l}\text { T1 } \\
\text { T2 } \\
\text { T3 }\end{array}$ & $\begin{array}{l}0.70(0.14) \\
0.65(0.21) \\
0.60(0.14)\end{array}$ & 0.176 & 0.846 & 0.105 \\
\hline \multirow{2}{*}{ Clustering coefficient } & 3 vs. 3 & $\begin{array}{l}\text { T1 } \\
\text { T2 } \\
\text { T3 }\end{array}$ & $\begin{array}{l}1.00(0.00) \\
1.00(0.00) \\
0.59(0.59)\end{array}$ & 1.000 & 0.465 & 0.400 \\
\hline & 5 vs. 5 & $\begin{array}{l}\text { T1 } \\
\text { T2 } \\
\text { T3 }\end{array}$ & $\begin{array}{l}0.37(0.52) \\
0.39(0.40) \\
0.20(0.14)\end{array}$ & 0.138 & 0.877 & 0.084 \\
\hline \multirow{2}{*}{ Total arcs } & 3 vs. 3 & $\begin{array}{l}\text { T1 } \\
\text { T2 } \\
\text { T3 }\end{array}$ & $\begin{array}{l}6.00(0.00) \\
6.00(0.00) \\
5.50(0.71)\end{array}$ & 1.000 & 0.465 & 0.400 \\
\hline & 5 vs. 5 & $\begin{array}{l}\text { T1 } \\
\text { T2 } \\
\text { T3 }\end{array}$ & $\begin{array}{l}14.00(2.83) \\
13.00(4.24) \\
12.00(2.83)\end{array}$ & 0.176 & 0.846 & 0.105 \\
\hline
\end{tabular}

Table 8. One-way ANOVA values of formats per task conditions for network density, clustering coefficient, and total arcs

\begin{tabular}{|c|c|c|c|c|c|c|}
\hline & & & $M(S D)$ & $F$ & $p$ & $\eta_{p}^{2}$ \\
\hline \multirow{3}{*}{ Network density } & Task 1 & $\begin{array}{l}3 \text { vs. } 3 \\
5 \text { vs. } 5\end{array}$ & $\begin{array}{l}1.00(0.00) \\
0.70(0.14)\end{array}$ & 9.000 & 0.095 & 0.818 \\
\hline & Task 2 & $\begin{array}{l}3 \text { vs. } 3 \\
5 \text { vs. } 5\end{array}$ & $\begin{array}{l}1.00(0.00) \\
0.65(0.21)\end{array}$ & 5.444 & 0.145 & 0.731 \\
\hline & Task 3 & $\begin{array}{l}3 \text { vs. } 3 \\
5 \text { vs. } 5\end{array}$ & $\begin{array}{l}0.92(0.12) \\
0.60(0.14)\end{array}$ & 5.761 & 0.138 & 0.742 \\
\hline \multirow{3}{*}{ Clustering coefficient } & Task 1 & $\begin{array}{l}3 \text { vs. } 3 \\
5 \text { vs. } 5\end{array}$ & $\begin{array}{l}1.00(0.00) \\
0.37(0.52)\end{array}$ & 3.027 & 0.224 & 0.602 \\
\hline & Task 2 & $\begin{array}{l}3 \text { vs. } 3 \\
5 \text { vs. } 5\end{array}$ & $\begin{array}{l}1.00(0.00) \\
0.39(0.40)\end{array}$ & 4.657 & 0.164 & 0.700 \\
\hline & Task 3 & $\begin{array}{l}3 \text { vs. } 3 \\
5 \text { vs. } 5\end{array}$ & $\begin{array}{l}0.59(0.59) \\
0.20(0.14)\end{array}$ & 0.813 & 0.462 & 0.289 \\
\hline \multirow{3}{*}{ Total arcs } & Task 1 & $\begin{array}{l}3 \text { vs. } 3 \\
5 \text { vs. } 5\end{array}$ & $\begin{array}{c}6.00(0.00) \\
14.00(2.83)\end{array}$ & 16.000 & 0.057 & 0.889 \\
\hline & Task 2 & $\begin{array}{l}3 \text { vs. } 3 \\
5 \text { vs. } 5\end{array}$ & $\begin{array}{c}6.00(0.00) \\
13.00(4.24)\end{array}$ & 5.444 & 0.145 & 0.731 \\
\hline & Task 3 & $\begin{array}{l}3 \text { vs. } 3 \\
5 \text { vs. } 5\end{array}$ & $\begin{array}{c}5.50(0.71) \\
12.00(2.83)\end{array}$ & 9.941 & 0.088 & 0.833 \\
\hline
\end{tabular}


$\eta_{p}^{2}=0.191$; small effect size) between format and task condition on network variables.

In the case of network density, clustering coefficient, and total arcs, a one-way ANOVA was performed for each independent variable because no interaction was found between factors. The statistical values that resulted from the comparison between task conditions are presented in Table 7 .

One-way ANOVA was also carried out to compare the values between formats for the variables of network density, clustering coefficient, and total arcs. The values can be verified in Table 8 .

\section{DISCUSSION}

This study aimed to analyse the effects of different SSGs and SSCGs in the technical, tactical, and physiological responses among youth football players. The main results showed that smaller format statistically increased technical performance. Nevertheless, different task conditions with tactical content did not result in statistical differences in technical and tactical variables.

Previous studies in SSGs have suggested that smaller formats statistically increases the heart rate responses in football players from different competitive levels [5]. In our study, no differences in heart rate responses were found between 3-a-side and 5-a-side formats among youth football players of U12 competitive level. Only in the specific zone 1, there were differences found, with 3-a-side spending a greater percentage of time in this specific zone. In fact, even different task conditions crossed with different formats did not affect the heart rate responses or time spent in heart rate zones. Such results in youth players may lead to a specific adaptation toward smaller formats because at this competitive level the official game format is the 7 -a-side game. Moreover, the technical level and strength and condition of these players may not be enough to differentiate the individual participation and time-motion profile in different formats.

On the other hand, statistical differences were found between formats in technical performance and collective organization measured by network analysis. The smaller format (3-a-side) resulted in greater levels of volume of play, efficiency index, and performance score than the 5-a-side game. This suggests that the smaller format is more appropriate to increase the individual participation of youth football players, helping to develop skill levels in the game. Our results are in line with previous studies that analysed individual actions performed during regular SSGs [25] and SSCGs [4].
In fact, the small number of players decreases the possibilities of passing, thus increasing the tendencies of playing with the players.

Despite this tendency to play with the same teammates in smaller formats, in our study this did not influence the collective patterns measured by network analysis. No statistical differences were found between formats for the variables of network density, total arcs, or clustering coefficient. Nevertheless, the average values showed that greater values of total arcs and density were present in the smaller format, revealing that the lack of options to play increases the ability to play together and to homogenize the cooperation of players.

In the case of the analysis performed between different task conditions (with different tactical content) it was possible to verify that a regular SSG statistically increased the time spent in zone 1 of heart rate intensity in comparison with the SSCG with attacking and defensive content. Nevertheless, no other statistical differences were found in the heart rate variables. This may suggest that the format may be the main variable to determine the physiological responses during SSGs. However, further studies must be carried out on this topic to verify such a possibility.

Moreover, no statistical differences were found in technical performance or collective organization between different task conditions with specific tactical contents. Despite changes in the rules and tactical missions, the variability of technical performance and collective organization was not significant. This can be partially justified by the small number of variables measured and by the fact that only attacking collective measurements were analysed. Maybe in the future, spatio-temporal measurements, such as wCentroid, wStretch index, effective area of play or tactical metrics, can be used to increase the understanding of how different conditions influence the performance of youth players.

This study had some limitations. The sample was not sufficiently large to generalize the results. Moreover, it will be useful in further research to compare a large spectrum of formats (from 2-a-side up to 7-a-side) and add more variables associated with spatio-temporal relationships. An intervention program based on SSCG in comparison with regular SSG can also be useful to test the real capacity of these games. In fact, it is possible that an SSCG with tactical content requires more time to understand the game and also to develop the tactical principles in it.

In future studies, larger formats (e.g., 6-a-side or 7 -a-side) should be compared with smaller formats (e.g., 3-a-side) to help analyse the variation of technical 
S. González-Víllora, F.M. Clemente, F.M.L. Martins, J.C. Pastor-Vicedo, Performance in conditioned soccer games

performance across different games and identify those which are more appropriate for specific ages or competitive level.

\section{CONCLUSIONS}

The study compared two formats (3-a-side and 5 -a-side) and task conditions with tactical content (regular, defensive, and attacking) in the physiological, technical, and tactical responses among youth football players. The main results proved that the format only had a statistical influence on the technical performance of the players. The task conditions had no statistical influence on the majority of variables. This may suggest that format is the main condition to change the physiological and technical responses of the players, and may help coaches to identify the best drills to apply in the early stages of football learning.

\section{Acknowledgements}

The authors would like to thank Albacete Balompié. The study was carried out within the scope of R\&D Unit 50008, financed by UID/EEA/50008/2013.

\section{Disclosure statement}

No author has any financial interest or received any financial benefit from this research.

\section{Conflict of interest}

Authors state no conflict of interest.

\section{References}

1. Davids K, Araújo D, Correia V, Vilar L. How small-sided and conditioned games enhance acquisition of movement and decision-making skills. Exerc Sport Sci Rev. 2013;41(3):154-161; doi: 10.1097/JES.0b013e318292f3ec.

2. Hill-Haas SV, Dawson B, Impellizzeri FM, Coutts AJ. Physiology of small-sided games training in football: a systematic review. Sports Med. 2011;41(3):199-220; doi: 10.2165/11539740-000000000-00000.

3. Mitchell SA, Oslin JL, Griffin LL. Teaching sport concepts and skills: a tactical games approach for ages 7 to 18. Champaign: Human Kinetics; 2006.

4. Clemente FM, Martins FML, Mendes RS. Developing aerobic and anaerobic fitness using small-sided soccer games: methodological proposals. Strength Cond J. 2014;36(3):76-87; doi: 10.1519/SSC.0000000000000063.

5. Owen AL, Wong DP, Paul D, Dellal A. Physical and technical comparisons between various-sided games within professional soccer. Int J Sports Med. 2014;35(4): 286-292; doi: 10.1055/s-0033-1351333.

6. González-Víllora S, García-López LM, Pastor-Vicedo JC, Contreras-Jordán OR. Tactical knowledge and decision making in young football players (10 years old). Rev Psicol Deporte. 2011;20(1):79-97.
7. Serra-Olivares J, González-Víllora S, García-López LM, Araújo D. Game-based approaches' pedagogical principles: exploring task constraints in youth soccer. J Hum Kinet.2015;46(1):251-261;doi:10.1515/hukin-2015-0053.

8. Aguiar M, Botelho G, Lago C, Maças V, Sampaio J. A review on the effects of soccer small-sided games. $J$ Hum Kinet. 2012;33:103-113; doi: 10.2478/v10078012-0049-x.

9. Hill-Haas SV, Dawson BT, Coutts AJ, Rowsell GJ. Physiological responses and time-motion characteristics of various small-sided soccer games in youth players. J Sports Sci.2009;27(1):1-8; doi:10.1080/02640410902761199.

10. Kelly DM, Drust B. The effect of pitch dimensions on heart rate responses and technical demands of smallsided soccer games in elite players. J Sci Med Sport. 2009;12(4):475-479; doi: 10.1016/j.jsams.2008.01.010.

11. Rampinini E, Impellizzeri FM, Castagna C, Abt G, Chamari K, Sassi A, et al. Factors influencing physiological responses to small-sided soccer games. J Sports Sci. 2007; 25(6):659-666; doi: 10.1080/02640410600811858.

12. Mallo J, Navarro E. Physical load imposed on soccer players during small-sided training games. J Sports Med Phys Fitness. 2008;48(2):166-171.

13. Evangelos B, Eleftherios M, Aris S, Ioannis G, Konstantinos A, Natalia K. Supernumerary in small sided games 3Vs3 \& 4Vs4. J Phys Educ Sport. 2012;12(3):398-406; doi: 10.7752/jpes.2012.03059.

14. Gréhaigne JF, Godbout P, Bouthier D. The foundations of tactics and strategy in team sports. J Teach Phys Educ. 1999;18(2):159-174; doi: 10.1123/jtpe.18.2.159.

15. González-Víllora S, García-López LM, Contreras-Jordán OR. Decision making and skill development in youth football players. Int J Med Sci Phys Act Sport. 2015; 15(59):467-487; doi: 10.15366/rimcafd2015.59.005.

16. Serra-Olivares J, González-Víllora S, García-López LM. Comparison of the performance of soccer players aged 8-9 years old in two modified games 3 against 3 [in Spanish]. Cuad Psicol Deporte. 2011;11(2):77-91.

17. Serra-Olivares J, González-Víllora S, García-López LM. Effects of modification of task constraints in 3-versus-3 small-sided soccer games. S Afr J Res Sport Phys Educ Recr. 2015;37(2):119-129.

18. Costa IT, Garganta J, Greco PJ, Mesquita I, Seabra A. Influence of relative age effects and quality of tactical behaviour in the performance of youth soccer players. Int J Perform Anal Sport. 2010;10(2):82-97; doi: 10.1080/24748668.2010.11868504.

19. Clemente FM, Martins FML, Kalamaras D, Wong DP, Mendes RS. General network analysis of national soccer teams in FIFA World Cup 2014. Int J Perform Anal Sport. 2015;15(1):80-96; doi:10.1080/24748668.2015.11868778.

20. Cotta C, Mora AM, Merelo JJ, Merelo-Molina C. A network analysis of the 2010 FIFA world cup champion team play. J Syst Sci Complexity. 2013;26(1):21-42; doi: 10.1007/s11424-013-2291-2.

21. Gréhaigne JF, Bouthier D, David B. Dynamic-system analysis of opponent relationship in collective actions in 
S. González-Víllora, F.M. Clemente, F.M.L. Martins, J.C. Pastor-Vicedo, Performance in conditioned soccer games

football. J Sports Sci. 1997;15(2):137-149; doi: 10.1080/ 026404197367416.

22. Gréhaigne JF, Richard JF, Griffin LL. Teaching and learning team sports and games. New York: Routledge; 2005.

23. Gréhaigne JF, Godbout P, Bouthier D. Performance assessment in team sports. J Teach Phys Educ. 1997;16(4): 500-516; doi: 10.1123/jtpe.16.4.500.

24. Robinson G, O’Donoghue P. A weighted kappa statistic for reliability testing in performance analysis of sport. Int J Perform Anal Sport. 2007;7(1):12-19; doi: 10.1080/ 24748668.2007.11868383.

25. Katis A, Kellis E. Effects of small-sided games on physical conditioning and performance in young soccer players. J Sports Sci Med. 2009;8(3):374-380. 